TELAGA BAHASA

Volume 5

No. 2 Desember 2017

Halaman 297-306

\title{
KELAS KATA ANTONIM DALAM BAHASA BANJAR
}

\section{(Word Class of Antonym in Banjarnese Language)}

\author{
Risarri Yayuk \\ Balai Bahasa Kalimantan Selatan \\ Jalan Ahmad Yani Km 32,2 Loktabat Utara, Banjarbaru Utara No 60 \\ Kalimantan Selatan, 70712 \\ Pos: el : yrissariyayuk@yahoo.co.id
}

\begin{abstract}
Abstrak
Kajian antonim merupkan bagian penting dalam semantik. Masalah penelitian ini meliputi bagaimana bentuk antonim bahasa Banjar berdasarkan kelas kata dan bagaimana membuktikan kadar keantoniman tersebut berdasarkan ciri kelas katanya. Tujuan yang ingin dicapai dalam penelitian adalah mendeskripsikan wujud antonim berdasarkan kelas katanya dan membuktikan kadar keantonimannya berdasarkan ciri kelas katanya.Metode yang digunakan dalam pengumpulan data adalah simak dengan teknik rekam dan catat. Sumber data berasal dari tuturan masyarakat Banjar di Kelurahan Loktabat, Banjarbaru, Provinsi Kalimantan Selatan. Waktu pengumpulan data pada bulan Januari 2016 s/d Juni 2016.Pada tahap analisis data menggunakan teknik perluas. Hasil analisis data disajikan secara deskriptif naratif dengan metode formal dan informal. Hasil penelitian (menunjukkan bahwa ada tiga jenis kelas kata antonim yang ditemukan), yaitu terdiri atas kelas kata sifat, kata kerja, dan kata benda. Pembuktian bahwa pasangan yang diperoleh tersebut adalah pasangankata antonim dalam kelasnya masing-masing karena sesuai dengan ciri-ciri di kelas masing-masing.
\end{abstract}

Kata kunci: Kata, antonim, Banjar

\begin{abstract}
Antonym study is an important part of semantic. This research problem includes how the form of antonym in Banjarnese language based on word classes and how to prove that level of antonym based on the characteristic of the word classes. The aims of this research are to describe the form of antonym based on the word classes and to prove that level of antonym based on the characteristic of the word classes. The methodology used for data
\end{abstract}


collection refers to observation method with recording and writing techniques. The data source comes from the public speech of Banjar people in Loktabat Village, Banjarbaru, South Kalimantan Province. The data were taken from January to June 2016. At the phase of analysis, the data were analyzed using the expansion technique. The results of data analysis were presented in narrative descriptive with informal and formal method. The result of this research had shown adjective class, verb, and noun. The proof of the pairs obtained is the antonym word pairs in their respective classes; it corresponds to the characteristics in each class.

Keywords: word, antonym, Banjarnese

\section{PENDAHULUAN}

Kalimantan Selatan memiliki salah satu bahasa daerah yang disebut dengan bahasa Banjar. Bahasa ini menjadi bahasa perhubungan antara suku maupun sesama suku Banjar. Berdasarkan hal ini, bahasa Banjar memiliki populasi yang besar dibanding penutur bahasa daerah lainnya di Provinsi tersebut.

Sekarang ini, bahasa Banjar menjadi materi muatan lokal bagi siswa di sekolah dasar maupun di tingkat lanjutan pertama. Akan tetapi dalam kenyataannya, sumber materi tentang bahasa Banjar sangatlah kurang. Penyebab kekurangan bahan ajar untuk muatan lokal ini antara lain, minimnya penelitian tentang bahasa Banjar, kurangnya pencetakan buku-buku tentang bahasa Banjar, jauhnya wadah penyedia bahan ajar dari tempat didik, dan pendistribusian tentang materi bahasa Banjar yang masih terbatas. Hal ini menjadi salah satu dasar pemikiran tentang pentingnya untuk menyediakan banyak sumber bahan ajar yang hasilnya nanti mudah didapatkan dan dimanfaatkan oleh pendidik dan peserta didik yang membutuhkannya.Salah satu pendukung bahan ajar yang dimaksud adalah kajian yang sedang peneliti lakukan ini.

Kajian materi yang diteliti adalah tentang antonimi dalam bahasa Banjar.Tarigan (2009:30) menyatakan bahwa antonim adalah terdiri atas kata anti atau ant yang berarti lawan. Ditambah akar kata onim atau onuma yang berarti nama.Jadi antonimi artinya kata yang mengandung makna yang berkebalikan. Tarigan (2009:31) menyatakan bahwa telaah tentang antonimi merupakan salah satu cara yang efektif untuk meningkatkan perbendaharaan dan keterampilan kosakata para siswa. Chaer (1995: 89) menyatakan antonim adalah oposisi makna yang tercakup dalam konsep yang betul-betul berlawanan sampai yang kontras. 
Penelitian tentang bahasa Banjar secara umum sudah pernah dilakukan. Djantera, dkk. (1986) mengkaji Morfologi sintaksis bahasa Banjar Kuala. Penelitian ini mendeskripsikan struktur morfogi dan sintaksis khusus untuk bahasa Banjar Kuala.. Yusof, dkk. (2010) Perkaitan Semantik Kata Kerja Bahasa Banjar Kuala: Satu Analisis Varian Kuin, Banjarmasin. Penelitian ini menjelaskan tentang hubungan semantik yang terdapat dalam kata kerja bahasa Banjar Kuala. Kawi tahun 2001 mengkaji Kata Kerja Bahasa Banjar Hulu. Pada penelitian ini hanya memuat antonim yang berkelas kata kerja. Ketiga penelitian tidak menyinggung tentang antonimi dengan kelasnya masing-masing. Untuk mengisi kerumpangan penelitian tersebut, peneliti tertarik untuk mengangkat permasalahan antonimi dalam bahasa Banjar.

Masalah penelitian ini meliputi bagaimana bentuk antonimi bahasa Banjar berdasarkan kelas kata dan bagaimana membuktikan kadar keantoniman tersebut berdasarkan ciri kelas katanya. Tujuan yang ingin dicapai dalam penelitian adalah mendeskripsikan wujud antonimi berdasarkan kelas katanya dan membuktikan kadar keantonimannya berdasarkan ciri kelas katanya. Dasar teori yang digunakan adalah kajian semantik. Ullman (dalam Sumarsono,
2014: 1 menyatakan bahwa semantik adalah ilmu makna atau studi tentang makna kata.

\section{TEORI}

Suwandi, ( 2011:1-2) menyatakan kata semantik diturunkan dari kata Yunani emainen (bermakna atau berarti) . Kata ini disepakati sebagai istilah untuk bidang ilmu bahasa yang membahas dan mempelajari tentang makna dan arti dalam sebuah komunikasi. Aminuddin ( 2008:15) menyatakan bahwa semantik mempunyai makna 'to signifity'(memaknai).Kridalaksana (2008:216) menyatakan semantik adalah bagian struktur bahasa yang berhubungan dengan makna ungkapan dan juga dengan struktur makna suatu wicara. Semantik adalah system dan penyelidikan makna dan arti dalam suatu bahasa atau bahasa pada umumnya. Sementara itu, Chaer (2009:2) menyatakan, semantik adalah ilmu tentang makna atau arti.

Semantik adalah salah satu tataran dalam analisis bahasa yang hanya berhubungan dengan makna dalam bahasa verbal.Makna ini terdapat dalam ujaran seperti kata, frase, klausa, dan kalimat.Makna ini akan diketahui jika menghubungkan antara kata atau simbol dengan konsep atau referensi dan hal yang diacu oleh makna tersebut.Salah satu pokok bahasan ilmu semantik adalah masalah kata antonim. 
Muhajir (2014:85) menyatakan bahwa masalah antonim merupakan salah satu bagian dari kajian semantik. Karim, dkk. (2013:43) menyatakan antonim adalah hubungan semantik antara dua buah satuan ujaran yang maknanya menyatakan kebalikan, pertentangan, atau kontras antara yang satu dengan yang lain. Parera (2009: 71-74) yang menyatakan antonim adalah pertentangan dua makna. Wijana (2015:55) menyatakan bahwa antonim adalah perlawanan makna.Kalimat yang menggunakan kata-kata antonim akan saling berkontradiksi satu sama lainnya. Muhadjir (2014:85) menyatakan bahwa antonim adalah pasangan kata yang memiliki relasi makna yang menyatakan pertentangan makna.

Dengan demikian, kata antonim adalah pasangan kata yang dari segi makna memiliki hubungan saling berlawanan pada oposisinya masing-masing. Rahyono (2012:159) menyatakan bahwa antonim mengacu pada oposisi yang bergradasi. Pasangan kata antonim menunjukkan gradasi makna yang diyatakan pasangan kata yang berantonim tersebut. Wijana (2015:55-60) menyatakan pasangan kata antonim beranggotakan kelas kata kata sifat, kata kerja, dan benda.

Nakhrawie (2008:5-22) menyatakan (1) kata sifat adalah kata yang menyatakan sifat atau hal keadaan dari suatu benda atau sesuatu yang dibendakan, Ciri kata sifat ini antaralain dapat didahului kata lebih, agak, paling, sangat, dan cukup. (2) Kata kerja adalah kata yang menyatakan perbuatan atau laku. Cirinya dapat diperluas dengan kata sedang dan mendapat imbuhan me-. (3) Kata benda adalah nama dari semua benda dan segala yang dibendakan. Kata benda ini terdiri atas kata benda berwujud dan tidak berwujud.Ciri kata benda adalah kata tersebut dapat diperluas dengan menambah kata yang + kata sifat atau dapat disandingkan dengan kata negasi bukan.

Berdasarkan pendapat di atas, yang dimaksudkan kelas kata pasangan kata antonim dalam penelitian ini meliputi (1) Kata antonim sifat adalah pasangan kata antonim yang terdiri atas kata sifat yang meliputi manusia, hewan, dan benda.Sebuah kata dikatakan termasuk kelas sifat jika bisa disandingkan dengan modalitas lebih, agak, paling, sangat, dan cukup.(2) Kata antonim kerja adalah pasangan kata antonim bermakna perbuatan yang memiliki ciri antara lain dapat diperluas dengan kata sedang dan mendapat imbuhan me-. (3) Kata antonim benda adalah adalah pasangan kata antonim yang beranggotakan kata benda, meliputi benda kongret dan abstrak. Benda kongret meliputi manusia, pohon, benda mati, dan binatang. Benda abstrak seperti konsep atau pengertian. 


\section{METODE}

Metode yang digunakan dalam pengumpulan data adalah simak dengan teknik rekam dan catat. Hal ini mengacu dengan apa yang dimaksudkan Makhsun (2005) .Peneliti menyimak tuturan lisan masyarakat Banjar di Kelurahan Loktabat, Banjarbaru, Provinsi Kalimantan Selatan. Selanjutnya merekam dan mendokumentasikannya dalam bentuk catatan. Waktu pengumpulan data pada bulan Januari 2016 s/d Juni 2016.Pada tahap analisis data menggunakan teknik perluas. Teknik ini untuk menentukan kadar keantoniman kata bahasa Banjar berdasarkan kerangka teori.Hasil analisis data disajikan secara deskriptif naratif dengan metode formal dan informal.

\section{PEMBAHASAN}

Pasangan kata antonim ini terdiri atas kata sifat, kata kerja, dan kata benda. Berdasarkan hasil penelitian kata antonim dalam bahasa Banjar memiliki ketiga kelas tersebut. Berikut contoh kata antonim dalam kalimat bahasa Banjarnya.

\section{Kelas Kata Sifat}

Data [1]

Sidin tuh urangnya katuju kuranglabih haja wan tatangga 'Beliau itu orangnya senang kurang lebih saja dengan tetangga'

Data [2]

Anak tuh jangan rajin dikuciaki, baik- buruk inya bagawian, iya anak saurang jua

'Anak itu jangan sering diteriaki, baik buruk pekerjaannya, dia anak sendiri juga'.

Data [3]

Bungul- pintar kakanak tuh tagantung kakanaknya jua, ada nang bujurbujur balajar ada nang kada.

'Bodoh-pintar anak-anak itu tergantung anak-anaknya juga, ada yang benar-benar belajar ada yang tidak.'

Data [4]

Biasaai inya tuh, kada rajin- kadang

kulir bila balajar

'Biasa dia itu kadang rajin kadang malas bila balajar'

Data [5]

Hirang -putih hidup ikam nang manantuakan kada urang pang

'Hitam putih hidup kamu yang menentukan bukan orang lah'

Data [1], [2], [3] ,[4], dan [5] menggunakan antonim yang memiliki kelas 
kata sifat. Pasangan antonim ini yaitu kurang-labih'kurang-lebih' yang terdapat dalam kalimat [1] Sidin tuh urangnya katuju kurang- labih haja lawan tatangga yang memiliki arti 'Beliau itu orangnya senang kurang lebih saja dengan tetangga'. Berikutnya pasangan kata antonim baikburuk 'baik- buruk' pada data [2] Anak tuh jangan rajin dikuciaki, baik- buruk inya bagawian, iya anak saurang jua yang memiliki arti‘Anak itu jangan sering diteriaki, baik buruk pekerjaannya, dia anak sendiri juga'. Pasangan kata antonim Bungulpintar 'Bodoh-pintar' pada data [3] Bungulpintar kakanak tuh tagantung kakanaknya jua, ada nang bujur-bujur balajar ada nang kada yang memiliki arti'bodoh-pintar anakanak itu tergantung anak-anaknya juga, ada yang benar-benar belajar ada yang tidak.' Pasangan kata antonim kada rajin- kadang kulir 'kadang rajin kadang malas' terdapat pada data [4] biasaai inya tuh, kada rajinkadang kulir bila balajar'biasa dia itu kadang rajin kadang malas bila balajar'. Terakhir pasangan kata antonim berkelas sifat yaitu hirang -putih 'hitam-putih' pada data [5] hirang -putih hidup ikam nang manantuakan kada urang pang yang artinya 'hitam putih hidup kamu yang menentukan bukan orang lah'

Kelima pasangankata antonim ini terbukti termasuk kata sifat karena dapat disandingkan antara lain dengan kata agak yang dalam bahasa Banjarnya adalah pina. Pasangan antonim tersebut jika di sandingkan dengan kata pina 'agak ' menjadi [1] pina kurang 'agak kurang' dan pina labih 'agak lebih', [2] pina baik 'agak baik' dan pina buruk 'agak buruk', [3] pina bungul ' agak bodoh' dan pina pintar 'agak pintar ', [4] pina rajin'agak rajin' dan pina kulir'agak malas, pina hirang'agak hitam' dan pina putih'agak putih', dan [5] pina hirang'agak hitam' dan pina putih 'agak putih'.

Kelima data ini sesuai dengan apa dimaksudkan Wijana (2015:55-60) dan Nakhrawie (2008:5-22) . Wijana (2015:5560) menyatakan salah satu kelas kata antonim adalah pasangan kata antonim beranggotakan kelas kata sifat. Sementara ituNakhrawie (2008:5-22) menyatakan kata sifat adalah kata yang menyatakan sifat atau hal keadaan dari suatu benda atau sesuatu yang dibendakan, Ciri kata sifat ini antaralain dapat didahului kata lebih, agak, paling, sangat, dan cukup.

\section{Kelas Kata Kerja}

Data [6]

Manukar-manjual kandaraan tuh hudah gawian hidin tumatan bahari

'Membeli-menjual kendaraan itu sudah pekerjaan beliau sejak dahulu'

Data [7] 
Hidup badangsanakan ituh biasa mambari-manarima yang artinya 'hidup haja saling mambari-manarima bersaudara itu biasa saja saling memberi-

'Hidup bersaudara itu biasa saja menerima'. Pasangan kata antonim kawinsaling memberi-menerima'

Data [8]

Umanya Aluh sudah rancak kawincarai

'Ibunya Aluh sudah sering kawincerai'

Data [9]

Ikam nih katuju banar bajalanan $\boldsymbol{k a}$ sana-ka mari kada karuan

'Kamu ini senang sekali berkunjung ke sana- ke mari tidak karuan'

Data [10]

Maju-mundur sabuah usaha dahanu tagantung pamarintah jua

Maju-mundur sebuah perusahaan kadang tergantung pemerintah juga

Data [6], [7], [8], [9], dan [10] menggunakan antonim yang memiliki kelas kata kerja.Pasangan antonim ini yaitu manukar -manjual 'membeli-menjual' yang terdapat dalam kalimatdata [6] Manukar manjual kandaraan tuh hudah gawian hidin tumatan bahari dengan arti 'membelimenjual kendaraan itu sudah pekerjaan beliau sejak dahulu'. Selanjutnya pasangan kata antonim mambari-manarima'memberimenerima' pada data [7] Hidup badangsanakan ituh biasa haja saling danlagimundur'sedang mundur'. carai'kawin-cerai' pada data [8] Umanya Aluh sudah rancak kawin-carai 'ibunya Aluh sudah sering kawin-cerai. Ka sana-ka mari 'ke sana-ke mari' pada data [9]' Ikam nih katuju banar bajalanan ka sana-ka mari kada karuan. 'Kamu ini senang sekali berkunjung ke sana- ke mari tidak karuan'. Pasangan antonim berikutnya maju-mundur 'maju-mundur' pada data [10] maju-mundur sabuah usaha dahanu tagantung pamarintah jua, maju-mundur sebuah perusahaan kadang tergantung pemerintah juga.

Kelima pasangankata antonim ini terbukti termasuk kata kerja karena dapat diperluas lawan 'dengan' + kata sifat dan mendapat imbuhan me-. Berdasarkan hal ini ketiga pasangan antonim data [6] dan data [7] memiliki ciri kata kerja, yaitu telah mendapat imbuhan me- pada pasangan kata [6]Manukar -manjual 'membeli-menjual', dan data [7] mambari-manarima'memberimenerima'. Data [8] kawin-carai'kawin-cerai menjadi lagi kawin 'sedang kawin' dan lagi carai 'sedang cerai'. Data [9] Ka sana-ka mari 'ke sana-ke mari' menjadi lagi ka sana 'sedang ke sana' dan lagi ka mari'sedang ke mari'. Data [10] maju-mundur 'majumundur' menjadi lagi maju'sedang maju' badangsanakan ituh biasa haja saling dan lagi mundur'sedang mundur'. 
Kelima data ini sesuai dengan apa dimaksudkan Wijana (2015:55-60) dan Nakhrawie (2008:5-22) . Wijana (2015:5560) menyatakan kelas kata antonim salah satunya meliputi kelas kata kerja .Nakhrawie (2008:5-22) Kata kerja adalah kata yang menyatakan perbuatan atau laku. Cirinya dapat diperluas dengan kata sedang atau mendapat imbuhan me-.

\section{Kelas Kata Benda}

Data [11]

Di lapangan banyak banar kada bibinian -kada lalakian lagi manuntun karasmin

'Di lapangan banyak sekali tidak perempuan-tidak laki-laki sedang menyaksikan pertunjukkan'

Data [12]

Barataan guru-murit SMP 6 Banjarbaru buka puasa di sakulahan samalam

'Semua guru-murid SMP 6 Banjarbaru buka puasa di sekolah kemarin' Data [13]

Abah-uma sudah lawa barambangan

'Ayah-ibu sudah lama berpisah rumah'

Data [14]

Muka-balakang rumahnya banyak kambang kananga
'Depan-belakang rumahnya banyak kembang kenanga'

Data [15]

Ikam jangan katuju mancangangi urang ka atas-ka bawah

'Kamu jangan senang melihat orang ke atas-ke bawah'

Kelima data ini menggunakan pasangan kata antonim yang berasal dari kelas kata benda. Pasangan tersebut yaitu kada bibinian -kada lalakian 'tidak perempuan-tidak lelaki' yang terdapat dalam data Data [11] di lapangan banyak banar kada bibinian -kada lalakian lagi manuntun karasmin dengan arti 'di lapangan banyak sekali tidak perempuan-tidak lakilaki sedang menyaksikan pertunjukkan'.Selanjutnya Pasangan kata antonim berkelas kata benda yaitu gurumurit'guru-murid yang terdapat dalam data [12] barataan guru-murit SMP 6 Banjarbaru buka puasa di sakulahan samalam yang artinya 'semua guru-murid SMP 6 Banjarbaru buka puasa di sekolah kemarin'. Pasangan kata antonim abah-uma'ayah'ibu' pada data [13] Abah-uma sudah lawas barambangan yang artinya 'Ayah-ibu sudah lama berpisah rumah'. Pasangan kata antonim berkelas benda muka-balakang 'di depan-'belakang' pada data [14] mukabalakang rumahnya banyak kambang Kananga 'di depan-belakang rumahnya 
banyak kembang kenanga'. Dan $k a$ atas-ka bawah 'ke atas- ke bawah' merupakan pasangan kata antonim berkelas kata benda yang terdapat pada data [15] Ikam jangan katuju mancangangi urang ka atas-ka bawah 'kamu jangan senang melihat orang ke ataske bawah'.

Kelima pasangankata antonim ini terbukti termasuk kata benda karena dapat diperluas dengan disandingkan kata yang+kata sifat dan mendapat imbuhan -an. Data [11] menggunakan imbuhan -an pada pasangan antonimnya, yaitu kada bibinian kada lalakian 'tidak perempuan-tidak lelaki'. Data [12] dan [13] dapat diperluas dengan menggunakan kaya yang kata sifat. Pada penelitian ini akan menggunakan perluasan kata sifatbaik 'baik'. Pada data [12] menjadi guru nang baik'guru yang baik' dan murit nang baik'murid yang baik'. Pada data [13] menjadi abah nang baik'ayah yang baik' dan uma nang baik 'ibu yang baik'.Pada data [14] dan [15] menggunakan perluasan kata negasi kada ' bukan'. Data [14] menjadi kada muka' bukan muka' dan kada balakang 'bukan belakang'.Dan data [15] $k a$ atas-ka bawah 'ke atas- ke bawah' menjadi kada ka atas'bukan ke atas' dan kada ka bawah 'bukan ke bawah'.

Kelima contoh antonim dalam data di atas merupakan kelas kata antonim yang maujud dan ada yang tidak maujud.
Ketiga data tersebut berdasarkan kelas dan cirinya sesuai dengan pa yang dimaksudkan Wijana (2015:55-60) dan Nakhrawie (2008:5-22) . Wijana (2015:55-60) menyatakan bahwa salah satu kelas kata antonim adalah kata benda. Nakhrawie (2008:5-22) menyatakan kelas kata benda dalam pasangan antonim adalah berbentuk mauujud dan tidak maujud. .Ciri kata benda adalah kata tersebut dapat diperluas dengan menggunakan imbuhan -an, menambah kata yang + kata sifat atau disandingkan dengan kata negasi bukan.

\section{PENUTUP}

Berdasarkan hasil penelitian diketahui bahwa antonim dalam bahasa Banjar yang terdapat dalam tuturan lisan masyarakat Banjar di Kelurahan Loktabat, Banjarbaru, Provinsi Kalimantan Selatan. terdiri atas kelas kata sifat, kata kerja, dan kata benda. Pembuktian bahwa pasangan yang diperoleh tersebut adalah pasangankata antonim termasuk kata sifat karena dapat disandingkan antara lain dengan kata agak yang dalam bahasa Banjarnya pina. Selanjutnya pembuktian bahwa pasangan yang diperoleh adalah pasangan kata kerja karena dapat diperluas lawan 'dengan' + kata sifat atau mendapat imbuhan me.Akhirnya kelas kata antonim berikutnya adalah kelas kata benda. Pembuktian 
Pembuktian bahwa pasangan yang diperoleh tersebut adalah pasangankata antonim benda benda karena dapat diperluas dengan disandingkan kata negasi bukan, yang+kata sifat dan mendapat imbuhan -an.

\section{DAFTAR PUSTAKA}

Aminuddin. 2008. Semantik Pengantar Studi Tentang Makna. Bandung: Sinar Baru Algensindo

Chaer, Abdul. 1997. Semantik Bahasa Indonesia. Jakarta: Rineka Cipta. . 2009. Pengantar Semantik. Jakarta: Rineka Cipta.

Djantera, dkk. 1986. Mengkaji Morfologi sintaksis Bahasa Banjar Kuala.Banjarbaru. Balai Bahasa Banjarmasin.

Karim, dkk. 2013. Semantik Bahasa Indonesia.Tangerang. Pustaka Mandiri.

Kawi, Djantera. 2001. Kata Kerja Bahasa Banjar Hulu. Banjarbaru: Balai Bahasa Banjarmasin

Kridalaksana, Harimurti. 2008. Kamus Linguistik. Jakarta: Gramedia Pustaka Utama.

Mahsun. 2005. Metode Penelitian Bahasa Tahapan Strategi, Metode, dan Tekniknya. Jakarta: PT
Muhadjir.2014. Semantik dan Pragmatik. Tangerang. Pustaka Mandiri.

Nakhrawie An Asrifin. 2008. Intisari Bahasa Sastra Indonesia.-:Agung Media Mulia.

Parera, J.D. 2009. Teori Semantik. Jakarta: Erlangga.

Rahyono, F.X. 2012. Studi Makna.Jakarta: Penaku. Raja Grafindo Persada.

Sumarsono. 2014. Semantik. Yogyakarta: Pustaka Pelajar.

Suwandi, Sarwiji.2011. Semantik: Pengantar Kajian Makna. Pustaka Pelajar: Surakarta.

Tarigan, Henry Guntur. 2009. Pengajaran Semantik. Bandung: Angkasa.

Wijana, I Dewa Putu, 2016. Pengantar Semantik. Yogyakarta: Pustaka Pelajar.

Yusof, Maslida, dkk. 2010. Perkaitan Semantik Kata Kerja Bahasa Banjar Kuala: Satu Analisis Varian Kuin, Banjarmasin. Jurnal Melayu (5): 87102. 